\title{
Presence of phytochemicals in fruits and leaves of guava (Psidium guajava Linn.) for cancer prevention: A mini review
}

\author{
Sudipta Biswas ${ }^{1}$, Partha Talukdar ${ }^{2}$ and Soumendra Nath Talapatra ${ }^{3 *}$ \\ ${ }^{1}$ Department of Chemistry, Seacom Skills University, Kendradangal, Shantiniketan, Birbhum - 731236, West Bengal, India \\ 2 Department of Botany, Serampore College, University of Calcutta, 8 William Carey Road, Serampore - 712201, West Bengal, India \\ ${ }^{3}$ Department of Biological Science, Seacom Skills University, Kendradangal, Shantiniketan, Birbhum - 731236, West Bengal, India
}

\begin{abstract}
The present review deals with the bioactive compounds (phytochemicals) in the fruits and leaves of guava (Psidium guajava Linn.). In the present study, an attempt was done to survey of literatures for exact solvent extraction to know exact phytocompound an d characterization by using instruments along with anticancer properties of these phytochemicals present in fruits and leaves of guava. The compila tion of available literatures of last 10 years can be suitable ready references for future experimental study as in vitro and in vivo as well as new drug design as phytomedicines for cancer therapy.
\end{abstract}

Keywords: Bioactive compounds, Psidium guajava, Guava fruits and leaves, Cancer therapy, Phytomedicines

Article Info: Received 18 June 2019; $\quad$ Review Completed 31 July 2019; $\quad$ Accepted 08 August 2019; Available online 20 August 2019

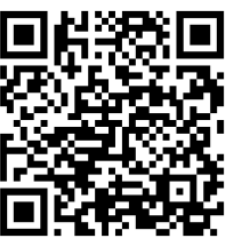

Cite this article as:

Biswas S, Talukdar P, Talapatra SN, Presence of phytochemicals in fruits and leaves of guava (Psidium guajava Linn.) for cancer prevention: A mini review, Journal of Drug Delivery and Therapeutics. 2019; 9(4-s):726-729

http://dx.doi.org/10.22270/jddt.v9i4-s.3290

Dr. Soumendra Nath Talapatra, Ph.D, Associate Professor, Department of Biological Science, Seacom Skills University, Kendradangal, Shantiniketan, Birbhum - 731236, West Bengal, India

\section{INTRODUCTION}

The guava tree (Psidium guajava Linn.) is a medicinal plant belonging the family Myrtaceae and found in the many places of India. The leaves and fruits are used for the traditional medicine worldwide ${ }^{1-4}$. In India, the fruits are edible food crop as low cost compared to other fruits and poor people can also afford as food 3,5 .

The leaves and fruits of guava contain several phytochemicals viz. tannins, phenols, triterpenes, $\beta$ avonoids, essential oils, saponins, carotenoids, lectins, vitamins, fibre and fatty acids 5-10 that prevent several diseases such as digestive disorders, cancers and mutations, bacterial infection, menstrual disorders, dermatitis, neurodegenerative disease, diabetes, lung problems, free radical generation, etc. ${ }^{4-6,11-13}$.

Several research works have already been emphasized that crude extracts of guava leaves and fruits are effective for anti-carcinogenicity 14-19 but few scattered animal studies were observed solvent isolated particular phytochemical(s) of leaves and fruits of guava plant potent to prevent cancer 9 , $14,19-22$.
Moreover, previous reports were obtained only on phytochemicals extraction and characterization by using instruments as well as separate experimentation on each phytocompound in animal models or cancer cell lines by researchers. The combination studies as extraction and characterization of phytocompounds of guava fruits and leaves as well as experiments on animal models with these extracts are rare 22-23. Major review works were observed on the disease prevention by using extracts of different parts of guava tree $2,4,19,24$.

In the present study an attempt was undertaken to compile research works of last 10 years to know cancer preventive phytochemicals present in the leaf and fruit of Psidium guajava Linn. from available literature as a ready reference for future research works for new drug design for cancer treatment.

\section{Study of solvent extraction for isolation and characterization of phytochemicals of fruits and leaves of guava}

It is very important to note that extraction by using proper solvent and isolation of exact phytocompound can be 
achieved as a suitable therapeutic agent. On the other hand, crude extract can also prevent cancer in in vitro as well as in vivo assay but exact phytocompound can be potential for new drug design as active ingredient. Numerous phytochemicals present in the fruits and leaves of guava Psidium guava Linn. and these were extracted in different solvents such as water, hexane, chloroform, methanol, ethanol, etc. and phytocompounds characterization by using different instruments 9-10 13, 22, 25-27. Researchers further used these phytochemicals in cancer therapy in animal models and in vitro study with cancer cell lines.

Jiménez-Escrig et al. 25 reported that ascorbic acid and tocopherol present in the fruits of P. guajava Linn. The extraction of fruit was done by using ethanol. Koo and Mohamed, 26 analysed phytochemicals Myricetin and Apigenin in dried plant samples especially edible part i.e. fruit of guava after extraction and hydrolysis of the flavonoid glycosides. The phytochemicals were determined from the methanol extract by using reversed-phase HPLC.

Arima and Danno 27 analysed phytocompounds that were isolated from leaves of guava ( $P$. guajava Linn.), and the structures of these compounds were confirmed based on chemical structure and spectroscopic evidence. The flavonoid glycosides namely Morin-3-0-alpha-Llyxopyranoside and Morin-3-0-alpha-L-arabopyranoside, and two known flavonoids, Guaijavarin and Quercetin were determined by them. The extraction was done with n-hexane and chloroform and the aqueous phase was extracted with ethyl acetate followed by separation under HPLC.

Chiari et al. ${ }^{13}$ studied the phytochemicals in the fruit extract of guava in hydroethanolic and aqueous solutions, which were analysed by using thin-layer chromatography (silica gel $60 \mathrm{~F} 254$ aluminum sheets, $20 \times 20 \mathrm{~cm}, 0.2 \mathrm{~mm}$ thickness, Sorbent Technologies). The HPLC-UV-PAD fingerprints of the fruit extracts obtained the main classes of phytochemicals were phenolic compounds, flavonoids, tannins, terpenes, steroids and reducing sugars. Interestingly, $70 \%$ ethanol was extracted suitable phytochemicals in the fruit.

Ryu et al. 22 identified phytochemicals in $80 \%$ methanol extract of the leaves of $P$. guajava Linn. Further, they fractionated with four different solvents such as the $n$ hexane fraction, chloroform fraction, ethyl acetate fraction, $n$-butanol fraction, and water fraction. They identified 60 types of phytocompounds in the $n$-hexane fraction of the leaf extract.

The gas chromatography-mass spectrometry (GC-MS) analysis revealed the identification of phytocompounds such as Pyrogallol, vitamin E, Palmitic acid, Caryophyllene oxide, Copaene, Alloaromadendrene, Caryophyllene, Sitosterol, $\alpha$ Bulnesene, $\alpha$-copaene, squalene, etc. in the methanol, chloroform and hexane extracts 28 .

Chiari-Andréo et al. 13 identified different phytocompounds such as Kaempferol 3-0-xylosyl-rutinoside, Quercetin, Quercetin 3-O-diglucoside, Catechin, -)- Epicatechin 8-Cgalactoside, etc. in the guava fruits. The total ion chromatogram obtained by negative-ion HPLC/MS/MS of E70 P. guajava L. extract.

Borah et al. 10 determined the phytochemical composition of the essential oil extracted from the leaves of P. guajava Linn. The leaves were hydro-distilled and phytocompounds were identified using GC-MS. Among 27 phytochemicals, major phytocompounds viz. $\alpha$-Terpinyl acetate, Transcaryophyllene, Nerolidol, $\alpha$-Cadinol, $\alpha$-Copaene and minor phytocompounds viz. $\alpha$-Humulene and (-)-Caryphyllene oxide were identified as essential oil by them.

\section{Cancer preventive phytochemicals in fruits and leaves of guava}

The carcinogenesis is a matter of great concern worldwide and researchers are showing interest on natural products to prevent cancer. It was also known that common phytochemicals present in the fruits and leaves of guava $P$. guava Linn. led to anti-inflammatory as well as anticarcinogenic properties studied by several researchers (Table 1) are as follows:

Sato et al. ${ }^{15}$ stated that phytocompounds viz. Ascorbic acid, Apigenin and Lycopene in the fruits of guava (P. guava Linn.) have potent anticarcinogenic effect while phytochemicals such as Gallic acid, Catechin, Epicatechin, Quercetin and Rutin in the leaves of guava observed to prevent breast cancer. They also reported guava fruit extract have ability to prevent cell proliferation of cancer cell lines during in vitro study. Nevertheless, Ascorbic acid of guava fruits also showed antioxidative properties.

Kim ${ }^{20}$ revealed that phytocompound Kaempferol of guava (P. guava Linn.) leaves has potent anticarcinogenic and antiproliferative properties on thyroid cancer cell lines. It was also reported that leaves of guava increased the rate of free radical scavenging activities supported antioxidant properties.

Ryu et al. 22 investigated different phytochemicals such as $\beta$ Eudesmol, $\alpha$-Copaene, Phytol, $\alpha$-Patchoulene, $\beta$ Caryophyllene oxide, Caryophylla-3(15), 7(14)-dien-6-ol, (E)-Methyl isoeugenol, $\alpha$-Terpineol, Hexadecane and Octadecane in the leaves of guava ( $P$. guava Linn.) after nhexane fraction. They observed that guava leaf hexane fraction (GHF) was the prominent inducer of cytotoxic and apoptotic effects in PC-3 (prostrate-cancer) cells. These mechanisms of GHF apoptotic potential were correlated with the suppression of AKT (protein kinase)/mTOR (mammalian target of rapamycin)/S6K1 (Ribosomal protein S6 kinase beta-1) and MAPK (Mitogen-activated protein kinases) signalling pathways. The GHF showed a correlation with down-regulation of several above-mentioned proteins, which remediate cell proliferation, cell survival, metastasis, and angiogenesis.

Bontempo et al. 21 investigated that the fruits of the guava $P$. guajava Linn. extract has potential for cancer prevention on both haematological and solid neoplasias. It has also observed that the extract of fruits reduced the tumour formation due to induction of apoptosis and differentiation. The ex vivo myeloid leukaemia blasts revealed that fruits were able to induce cell death but did not exhibit anti-cancer effects on all malignant cells investigated, indicating selective activity against specific tumour. According to them, active antineoplastic phytocompounds of the fruits involved Ursolic acid, Oleanolic acid, Arjunolic acid, Glucuronic acid, Oleandolic acid, Morin3-O-a-L-lyxopyranoside, Morin-3-0-aLarabinopyranoside, Pentane-2-thiol, Guaijavarin and Quercetin respectively.

El-Ahmady et al. 23 determined the dominant phytocompounds were $\beta$-Caryophyllene and Limonene in the P. guajava Linn. as fruit oil and $\beta$-Caryophyllene and Selin-7(11)-en- $4 \alpha$-ol as leaf oil. It was observed both essential oils have the ability to prevent free radical generating activities and effective for antioxidant activities. This antioxidative ability may prevent the cancer and inflammation. 
Chen et al. 14 evaluated antioxidant and the antiproliferative abilities of guava fruit (peel and flesh) on four cancer cell lines such as human lung cancer cells (A549), human breast cancer cells (MCF-7), human hepatoma cells (HepG2) and human colon cancer cells (HT-29) through the MTT assay. The phytocompounds viz. Catechin, Galangin, Homogentisic acid, Gallic acid, Kaempferol and Cyanidin 3-glucoside were reported suitable for antioxidant, antiproliferative and anticancer agents.
Ashraf et al. 28 reported that $P$. guajava Linn. contained several phytochemicals in the leaves and observed antiinflammatory and modulation of the NF-kB activation. The activation of NF-kB-regulated genes were associated with cellular transformation, proliferation, angiogensis, invasion, tumour cell survival and metastasis. Although, these phytochemicals have also potent anticarcinogenic properties.

Table 1. Anti-carcinogenic properties of phytochemicals in leaf and fruit of guava

\begin{tabular}{|c|c|c|c|c|}
\hline $\begin{array}{l}\text { Sl. } \\
\text { No. }\end{array}$ & $\begin{array}{l}\text { Leaves or } \\
\text { Fruits }\end{array}$ & Bioactive compounds & Preventive properties & References \\
\hline 1. & Fruits & Ascorbic acid, Apigenin and Lycopene & $\begin{array}{l}\text { Anticarcinogenic, } \\
\text { antiproliferative and } \\
\text { antioxidative }\end{array}$ & Sato et al., 15 \\
\hline 2. & Leaves & $\begin{array}{l}\text { Gallic acid, Catechin, Epicatechin, Quercetin and } \\
\text { Rutin }\end{array}$ & Anti-breast cancer & Sato et al., 15 \\
\hline 2. & Leaves & Kaempferol & $\begin{array}{l}\text { Anticarcinogenic, } \\
\text { antiproliferative and } \\
\text { antioxidative }\end{array}$ & Kim, 20 \\
\hline 3. & Leaves & $\begin{array}{l}\beta \text {-Eudesmol, } \alpha \text {-Copaene, Phytol, } \alpha \text {-Patchoulene, } \\
\beta \text {-Caryophyllene oxide, Caryophylla-3(15), } \\
7(14) \text {-dien-6-ol, }(E) \text {-Methyl isoeugenol, } \alpha- \\
\text { Terpineol, Hexadecane and Octadecane }\end{array}$ & $\begin{array}{l}\text { Anticarcinogenic and } \\
\text { antitumorigenic }\end{array}$ & Ryu et al., 22 \\
\hline 4. & Fruits & $\begin{array}{l}\text { Ursolic acid, Oleanolic acid, Arjunolic acid, } \\
\text { Glucuronic acid, Oleandolic acid, Morin3-O-a-L- } \\
\text { lyxopyranoside, morin-3-O-a- } \\
\text { Larabinopyranoside, Pentane-2-thiol } \\
\text { Guaijavarin and Quercetin }\end{array}$ & $\begin{array}{l}\text { Anticarcinogenic induced } \\
\text { apoptosis, antiproliferative, } \\
\text { non-malignancy, antineoplastic } \\
\text { effect }\end{array}$ & Bontempo et al., 21 \\
\hline 5. & Fruits & $\beta$-Caryophyllene and Limonene & $\begin{array}{l}\text { Antiinflammatory and } \\
\text { anticarcinogenic }\end{array}$ & El-Ahmady et al., ${ }^{23}$ \\
\hline 6. & Leaves & $\beta$-Caryophyllene and Selin-7(11)-en-4 $\alpha$-ol & $\begin{array}{l}\text { Antiinflammatory and } \\
\text { anticarcinogenic }\end{array}$ & El-Ahmady et al., 23 \\
\hline 7. & Fruits & $\begin{array}{l}\text { Catechin, Galangin, Homogentisic acid, Gallic } \\
\text { acid, Kaempferol and Cyanidin 3-glucoside }\end{array}$ & $\begin{array}{l}\text { Antioxidant, antiproliferative } \\
\text { and anticarcinogenic }\end{array}$ & Chen et al., 14 \\
\hline 8. & Leaves & $\begin{array}{l}\text { Caryophyllene, vitamin E, } \alpha \text {-Copaene, } \\
\text { Heneicosane, Pyrogallol, palmitic acid, } \\
\text { Caryophyllene oxide, Alloaromadendrene, } \\
\text { Sitosterol, } \alpha \text {-Bulnesene and Squalene }\end{array}$ & $\begin{array}{l}\text { Antiinflammatory, and } \\
\text { anticarcinogenic }\end{array}$ & Ashraf et al., 28 \\
\hline 9. & Fruits & $\begin{array}{l}\text { 3-Methoxysinensetin, Kaempferol, Kaempferol } \\
\text { 3-0-xylosyl-rutinoside, Quercetin, Schottenol } \\
\text { ferulate, 3-Methoxysinensetin and Sesamolinol } \\
\text { 4'-0-b-D-glucosyl (1->6)-0-b-D-glucoside }\end{array}$ & $\begin{array}{l}\text { Anticarcinogenic and } \\
\text { antioxidant }\end{array}$ & $\begin{array}{l}\text { Chiari-Andréo et } \\
\text { al., } 9\end{array}$ \\
\hline 10. & Fruits & Lycopene & $\begin{array}{l}\text { Antioxidative and } \\
\text { anticarcinogenic }\end{array}$ & Kaur et al., 19 \\
\hline 11. & Leaves & Kaempferol & Anticarcinogenic & Kaur et al., 19 \\
\hline 12. & Leaves & $\begin{array}{l}\text { Gallic acid, Catechin, Epicatechin, Rutin and } \\
\text { Quercetin }\end{array}$ & $\begin{array}{l}\text { Anticarcinogenic and } \\
\text { antiproliferative }\end{array}$ & Bijauliya et al., 24 \\
\hline
\end{tabular}

Chiari-Andréo et al. ${ }^{9}$ reported fruit phytochemicals such as Quercetin, Kaempferol, Schottenol of guava (P. guajava Linn.), which had strong antioxidant effect on superoxide dismutase (SOD) enzyme. This antioxidant activity may lead to prevent oxidative stress and possibly cancer.

Kaur et al. ${ }^{19}$ reviewed that Lycopene in the fruits of guava (P. guajava Linn.) showed powerful antioxidative properties, which helped the body to prevent from the harmful free radicals and increased the generation of free radicals may lead to cancer. According to them, guava fruit is suitable for decreased oxidative damage and prevent cancer. On the other hand, guava leaf phytochemical namely Kaempferol has potent anticarcinogenic properties.
Bijauliya et al.24 reviewed that aqueous extract of phytochemicals such as Gallic acid, Catechin, Epicatechin, Rutin and Quercetin of leaves of guava (P. guajava Linn.) observed anticarcinogenic properties. This extract containing phytochemicals are suitable for antiproliferative and antitumorigenic effect.

\section{CONCLUSIONS}

It is concluded from above-mentioned compilation of different research works that phytochemicals or bioactive compounds mainly polyphenols and flavonoids as well as essential oils of guava (P. guajava Linn.) fruits and leaves are suitable for antioxidative, antiproliferative, antitumorigenic and anticarcinogenic potential. Moreover, the solvent 
extraction is very essential to isolate exact phytochemical and each phytoconstitute can be used as phytomedicine for future drug design in cancer therapy. This present review work was compiled from available literatures with special reference to the process of isolation of phytochemicals by using instruments and experimentation on different cancer cell lines and colorimetric assay with these phytochemicals for cancer therapy as ready references for the academicians, researchers, pharmaceutical industries, etc. Further, it is suggested functional assay and bioavailability along with different pharmacological tests to detect specific cancer treatment by individual phytochemical.

\section{REFERENCES}

1. Gutiérrez RM, Mitchell S, Solis RV. Psidium guajava: A review of its traditional uses, phytochemistry and pharmacology. Journal of Ethnopharmacology, 2008; 117(1):1-27.

2. Shruthi SD, Roshan A, Timilsina SS, Sunita S. A review on the medicinal plant Psidium guajava Linn. (Myrtaceae). Journal of Drug Delivery \& Therapeutics, 2013; 3(2):162-168.

3. Daswani PG, Gholkar MS, Birdi TJ. Psidium guajava: A single plant for multiple health problems of rural Indian population. Pharmacognosy Reviews, 2017; 11(22): 167-174.

4. Naseer S, Hussain S, Naeem N, Pervaiz M, Rahman M. The phytochemistry and medicinal value of Psidium guajava (guava). Clinical Phytoscience, 2018; 4:32. doi.org/10.1186/s40816-018-0093-8

5. Kamath JV, Rahul N, Ashok Kumar CK, Mohana Lakshmi S. Psidium guajava L: A review. International Journal of Green Pharmacy, 2008; 2(1):9-12.

6. Begum S, Hassan SI, Ali SN, Siddiqui BS. Chemical constituents from the leaves of Psidium guajava, Natural Product Research, 2004; 18(2):135-140.

7. Roy CK, Kamath JV, Asad M, Hepatoprotective activity of Psidium guajava L leaf extract, The Indian Journal of Experimental Biology, 2006; 44(4):305-311.

8. Rishika D, Sharma R. An update of pharmacological activity of Psidium guajava in the management of various disorders. International Journal of Pharmaceutical Sciences and Research, 2012; 3(10):3577-3584.

9. Chiari-Andréo BG, Trovatti E, Marto J, de Almeida-Cincotto MGJ, Melero A, Corrêa MA, Leila Chiavacci A, Ribeiro H, Garrigues T, Isaac VLB. Guava: phytochemical composition of a potential source of antioxidants for cosmetic and/or dermatological applications. Brazilian Journal of Pharmaceutical Sciences, 2017; 53(2):e16141. doi.org/10.1590/s2175-9790201700 0216141

10. Borah A, Pandey SK, Haldar S, Lal M. Chemical composition of leaf essential oil of Psidium guajava L. from North East India. Journal of Essential Oil Bearing Plants, 2019; 22(1):248-253.

11. Cheng, JT, Yang RS, Hypoglycemic effect of guava juice in mice and human subjects. The American Journal of Clinical Medicine, 1983; 11(1-4):74-76.

12. Grover IS, Bala S, Study on antimutagenic effects of guava in $S$ typhimurium. Mutation Research/Genetic Toxicology, 1993; 300(1):1-3.

13. Chiari BG, Severi JA, de pauli-credendio PA, de Sylos CM, Vilegas W, Corrêa MA, Isaac VLB. Assessment of the chemical profile, polyphenol content and antioxidant activity in extracts of
Psidium guajava L. fruits. International Journal of Pharmacy and Pharmaceutical Sciences, 2012; 4(5):331-336.

14. Chen Y-H, Zhou T, Zhang Y-J, Zou Z-F, Wang F, Xu D-P. Evaluation of antioxidant and anticancer activities of guava. International Journal of Food Nutrition and Safety, 2015; 6(1): 1-9.

15. Sato R, Dang K, McPherson B, Brown AC. Anticancer activity of guava (Psidium guajava) extracts. Journal of Complementary and Integrative Medicine, 2010; 7(1):Article 43. doi: 10.2202/1553-3840.1361

16. Sul'ain MD, Zazali KE, Ahmad N. Screening on anti-proliferative activity of Psidium guajava leaves extract towards selected cancer cell lines. Journal of US-China Medical Science, 2012; 9(1):30-37.

17. Correa MG, Couto JS, Teodoro AJ. Anticancer properties of Psidium guajava - A mini-review. Asian Pacific Journal of Cancer Prevention, 2016; 17:4199-4204.

18. Regina MR, Santosh Kumar M. The active potential of guava Psidium guajava (L.) leaves extract and its anticancer activity. International Journal of Multidisciplinary Research and Development, 2017; 4(7):475-478.

19. Kaur M, Singh J, Mirza A. Pharmacological and medicinal properties of Psidium guajava: A review. Research Journal of Chemical and Environmental Sciences, 2018; 6(4): 70-73.

20. Kim TY. Antiproliferation and dedifferentiation in thyroid cancer cell lines by polyphenol phytochemicals. Journal of Korean Medical Science, 2011; 26:893-899.

21. Bontempo P, Doto A, Miceli M, Mita L, Benedetti R. Psidium guajava L. anti-neoplastic effects: induction of apoptosis and cell differentiation. Cell Proliferation, 2012; 45:22-31.

22. Ryu NH, Park KR, Kim SM, Yun HM, Nam D, Lee SG, Jang HJ, Ahn KS, Kim SH, Shim BS, Choi SH, Mosaddik A, Cho SK, Ahn KS. A hexane fraction of guava Leaves (Psidium guajava L.) induces anticancer activity by suppressing AKT/mammalian target of rapamycin/ribosomal p70 S6 kinase in human prostate cancer cells. Journal of Medicinal Food, 2012; 15(3):231-241.

23. El-Ahmady SH, Ashour ML, Wink M. Chemical composition and anti-inflammatory activity of the essential oils of Psidium guajava fruits and leaves. Journal of Essential Oil Research, 2013; 25(6): 475-481.

24. Bijauliya RK, Alok S, Kumar M, Chanchal DK, Sabharwal M, Yadav RD. An update of pharmacological activity of Psidium guajava in the treatment of various diseases. International Journal of Pharmaceutical Sciences and Research, 2018; 9(3):883-893.

25. Jiménez-Escrig, A.; Rincón, M.; Pulido, R.; Sauracalixto, F. Guava fruit (Psidium guajava L.) as a new source of antioxidant dietary fiber. Journal of Agricultural and Food Chemistry, 2001; 49(11):5489-5493.

26. Koo MH, Mohamed S. Flavonoid (myricetin, quercetin, kaempferol, luteolin and apigenin) content of edible tropical plants. Journal of Agricultural and Food Chemistry, 2001; 49(6): 3106-3112.

27. Arima H, Danno G. Isolation of antimicrobial compounds from guava (Psidium guajava L.) and their structural elucidation. Bioscience Biotechnology and Biochemistry, 2002; 66:17271730.

28. Ashraf A, Sarfraz RA, Rashid MA, Mahmood A, Shahid M, Noor N. Chemical composition, antioxidant, antitumor, anticancer and cytotoxic effects of Psidium guajava leaf extracts. Pharmaceutical Biology, 2016; 54(10):1971-1981. 